\title{
Climatic Factors Affecting Post-Harvest Decay of Jamaican Bananas ${ }^{1}$
}

\author{
C. A. Shillingford ${ }^{2}$
}

\begin{abstract}
Neck and crown rots of Jamaica-grown bananas (Musa sp.) are caused principally by Colletotrichum musae and Fusarium semitectum. Severity of decay and shrinkage of export fruit were positively correlated with periods of high temperature in the field, but there was no correlation with rainfall. High moisture is known to favour infection, but hot, dry conditions predisposed banana fruits to rapid decay. Control of neck and crown rots should include retardation of disease development by storage at low temperature and high humidity.
\end{abstract}

\section{INTRODUCTION}

Crown rot and wound (nonlatent) anthracnose are the major postharvest rots of commercial Cavendish bananas (Musa AAA group) in Jamaica $(13,14)$. Crown rot is caused by the invasion of freshly severed banana hands by a fungal complex including Fusarium semitectum Berk \& Rav., Colletotrichum musae (Berk \& Curt.) Arx, Botryodiplodia theobromae Pat. and Verticillium theobromae (Turc.) Mason \& Hughes (4, $9,14)$. These fungi are common saprophytes on trash banana leaves, decaying inflorescence bracts and dried flowers $(8,11,15)$. Conidia of these fungi may be dispersed by air or splashing rain and are abundant in washing tanks of boxing plants $(8,12,16)$. Fruit may be infected in the field or during the 2- to 3-day period of harvesting and processing (13).

Seasonal variation in inoculum $(11,12)$ and infection $(9,10)$ suggest that climatic factors influence the occurrence of banana fruit decay. Anthracnose was most prevalent in Jamaica from October to March, becoming less in April to September (10). In Honduras, crown rot is highest from March to September, diminishing from October to February (9).

This paper reports an investigation of possible correlations between temperature, rainfall, and humidity, and severity of post-harvest decay of Jamaica-grown bananas shipped to the United Kingdom.

\section{MATERIALS AND METHODS \\ FRUIT DECAY AND SHRINKAGE}

Data on the amount of crown rot, neck rot and shrinkage were extracted from the quality control reports (1969 through 1974), which were submit-

${ }^{1}$ Manuscript submitted to editorial Board April 24, 1978.

${ }^{2}$ Plant Pathologist, Research Department, Banana Board, Kingston, Jamaica. The author is indebted to Professor J. B. Sinclair, Department of Plant Pathology, University of Illinois for help in preparation of the manuscript; the Jamaica Meteorological Service for climatological data; and the Banana Board of Jamaica for permission to publish this work. 
ted to the Jamaica Banana Board by its shipping and marketing agents (Fyffes Group Ltd. and Jamaica Banana Producers' Association Ltd.). About $2.5 \%$ of the green bananas in each of 47 to 108 shipments per year from Jamaica to the United Kingdom (U.K.) were randomly selected for inspection at the port of entry and graded for various quality defects by quality assessors. Each hand was rated for the amount of crown rot as light (less than one-quarter decayed), medium (between one-quarter and one-half decayed), and severe (more than one-half decayed); for neck rot as light (one decayed pedicel per hand), medium (two decayed pedicels per hand), and severe (more than two decayed pedicels per hand). Fruits

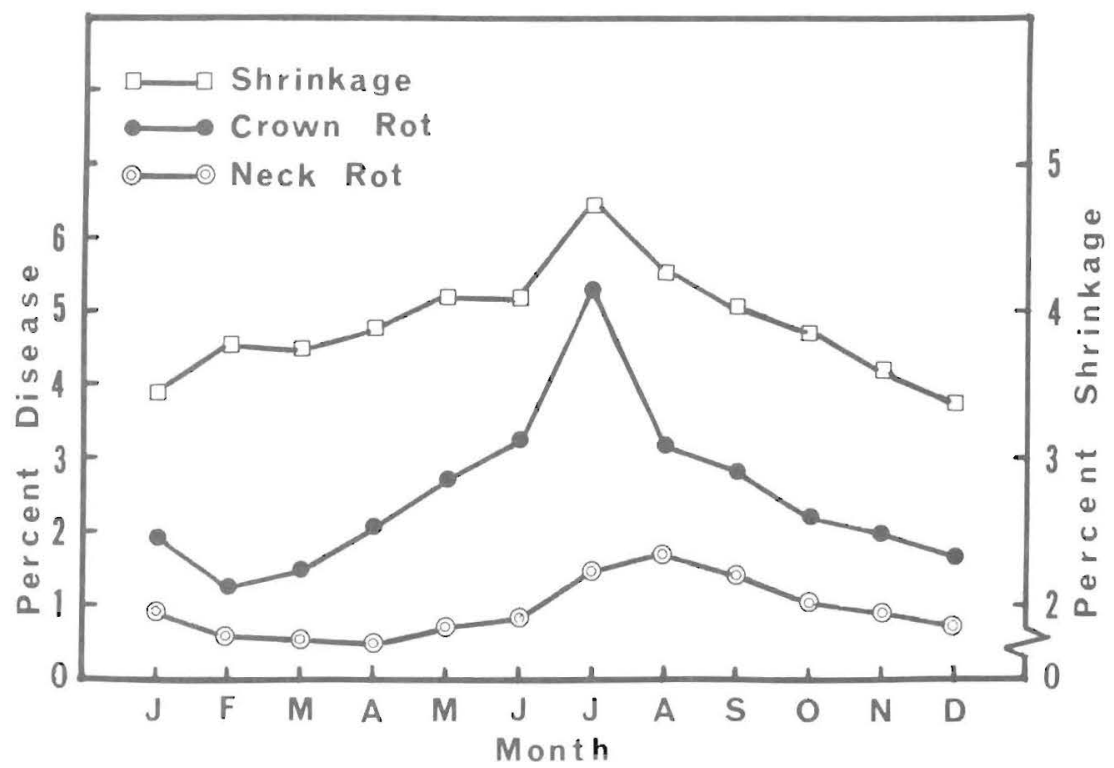

FIG. 1.-The relationship of mean percentage banana (Musa sp.) fruit decay and shrinkage to month of harvest for the years 1969-1974.

with light ratings for both diseases were considered as commercially acceptable and these ratings were not recorded in Fyffes' quality control reports. Shrinkage of the fruit was calculated from the percentage weight loss during port storage in Jamaica and shipment to the port of entry in the U.K.

\section{CLIMATIC DATA}

The mean monthly rainfall and temperature data for the major bananaproducing parishes of Jamaica (St. Mary, Portland, Manchester, St. James and St. Thomas) were obtained from the Jamaican Meteorological Service for the period 1969 through 1974. Relative humidity and evapo- 
ration data were recorded for several stations over the entire island and reflected the rainfall pattern with May and October peaks (2).

\section{RESULTS AND DISCUSSIONS}

The 6-yr means for percentage medium and severe crown rot showed a high incidence from May through September with a peak in July (fig. 1). The incidence of neck rot followed a similar pattern with a peak in August. There was less fruit rot and shrinkage in October through April. The percentage shrinkage increased with increase in the two

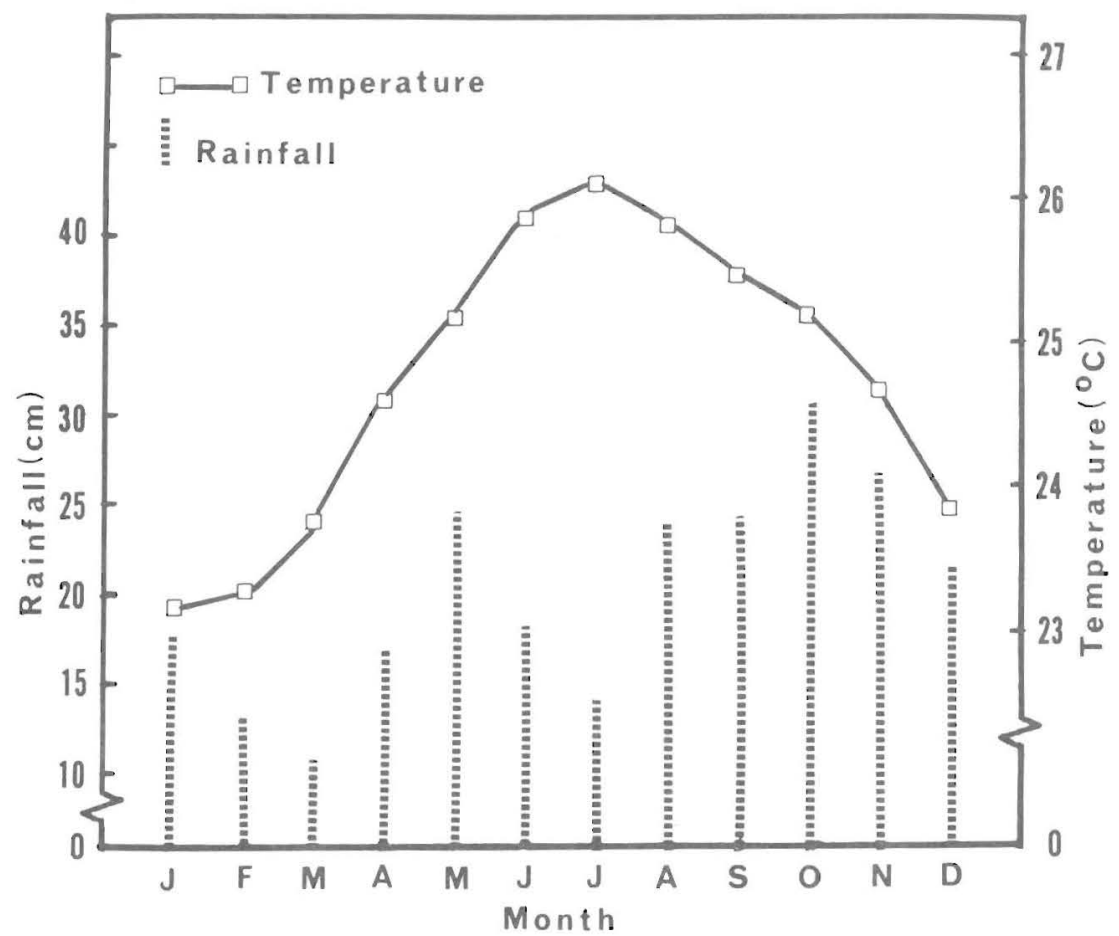

FIG. 2.-Six-year (1969-1974) mean monthly rainfall and temperature for the major banana (Musa sp.) growing parishes in Jamaica.

diseases. There was positive correlation between crown rot and shrinkage $(r=0.79$ at $P=0.01)$ and neck rot and shrinkage $(r=0.62$ at $P=0.05)$.

Jamaica's rainfall and relative humidity are bimodal with peaks in May and October and minima in March and July (2) (fig. 2). Minimum and maximum temperature occur in January and July, respectively. Shrinkage was highly correlated with temperature $(r=0.85$ at $P=0.01)$ but not rainfall ( $r=0.07$ ). Data from the Meteorological Service indicated that the highest evaporation occurred between May and July and the lowest 
from October to February (2). Decay, highest in July, corresponded to the highest temperature combined with low relative humidity. Shrinkage and disease occurrence were less during the cooler moister months.

Previous studies on the epidemiology of banana fruit decay have concentrated on climatological and biological factors as they affect inoculum production, dissemination and infection $(1,3,8,11)$. It was found that humidity at saturation or liquid water was necessary for infection in the field. Lukezic et al (9) observed fluctuations in the incidence of crown rot over a 10 -month period but they were unable to correlate them with change in frequency of fungal spores on the crown surface, suggesting that factors other than inoculum played a significant part in disease development.

Results reported here suggest that rapid decay probably depends on climatic factors in the field and during inland transit which facilitate fungal invasion of host tissues. Banana fungi grow rapidly at tropical temperatures $(3,17)$, but these temperatures also accelerate fruit metabolism. The biochemical changes associated with increased metabolism may form the basis for increased susceptibility of banana tissues to fungal attack (13). In a similar way, water loss from preclimacteric bananas was shown to increase ethylene production and respiratory gas exchange resulting in reduced green-life $(5,6,7)$. Moreover, Greene and Goos (4) showed that after dehanding, conidia can be drawn into vascular tissues of the crown to a depth of 5 to $7 \mathrm{~mm}$. Thus, fruit shrinkage, by causing further retraction of xylem water columns in banana crowns, could result in the drawing of conidia into inaccessible sites almost impossible to be reached by surface application of nonsystemic fungicides.

Results from this and other studies $(13,14,15)$ suggest that some of the steps necessary for the control of post-harvest decay of banana are 1) immediate cooling of fruit after harvest or avoidance of long exposure to tropical temperature; and 2) maintenance of high humidity during storage, transit and ripening to reduce water loss. The optimum temperature/humidity combinations to be used at different stages of storage before and after shipment require more study.

\section{RESUMEN}

Las podredumbres de la corona y el pédúnculo del bananero cultivado en Jamaica son causadas principalmente por Colletotrichum musae y Fusarium semitectum. La severidad del deterioro y el arrugamiento de la fruta de exportación estuvieron correlacionados positivamente con períodos de temperaturas altas en el campo, pero no con la lluvia. La mucha humedad favorece la infección, pero condiciones secas y calientes predisponen las frutas a un rápido deterioro. El combate de estas dos pudriciones debería incluir el detener el desarrollo de la enfermedad almacenando las frutas a una temperatura baja y mantener el ambiente bien húmedo durante el almacenamiento, transporte y maduración para evitar la pérdida de agua.

El trabajo se efectuó tomando muestras al azar de bananos verdes de cada embarque destinado al Reino Unido. 


\section{LITERATURE CITED}

1. Badger, A. M., 1965. Influence of relative humidity on fungi causing crown rot of boxed bananas. Phytopathology 55: 688-92.

2. Climatological Branch, Jamaican Meteorological Service. 1973. The climate of Jamaica, Jam. Meteorol. Serv., Kingston. 68 pp.

3. Goos, R. D. and Tschirsch, M., 1962. Effect of environmental factors on spore germination, spore survival and growth of Gloeosporium musarum, Mycologia 54: 353-67.

4. Greene, G. L. and Goos, R. D., 1963. Fungi associated with crown rot of boxed bananas, Phytopathology 53: 271-5.

5. Littmann, M. D., 1972. Effect of water loss on the ripening of climacteric fruits, Queens. J. Agri. Anim. Sci. 29: 103-13.

6. - 1972. Effect of water stress on the respiratory gas exchange of banana fruit and tissue, Queens. J. Agri. Anim. Sci. 29: 115-30.

7. — 1972. Effect of water stress on ethylene production by preclimacteric banana fruit, Queens. J. Agri. Anim. Sci. 29: 131-6.

8. Lukezic, F. L. and Kaiser, W. J., 1966. Aerobiology of Fusarium roseum "Gibbosum" associated with crown rot of boxed bananas, Phytopathology 56: 545-8.

9. _ , F. L., Kaiser, W. J., and Martinez, M. M., 1967. The incidence of crown rot of boxed bananas in relation to microbial populations of the crown tissue, Can. J. Bot. 45: 413-21.

10. Meredith, D. S., 1960. Studies on Gloeosporium musarum Cke. and Massee causing storage rots of Jamaican bananas. 2. Some factors influencing anthracnose development, Ann. Appl. Biol. 48: 518-28.

11. - 1962. Some fungi on decaying banana leaves in Jamaica, Trans. Br. Mycol. Soc. 45: $335-47$.

12. - - 1962. Some components of the air-spora of Jamaican banana plantations, Ann. Appl. Biol, 50: 577-94.

13. - 1971. Transport and storage diseases of bananas: biology and control, Trop. Agri. Trinidad 48: 35-50.

14. Shillingford, C. A., 1970. Banana fruit rot control in Jamaica, PANS 16: 69-75.

15. —, 1976. Occurrence of banana fruit rot fungi in Jamaican boxing plants, Plant Dis. Rep. 60: 788-93.

16. Stover, R. H., 1972. Banana, plantain and abaca diseases. Commonw. Mycol. Inst., Kew, $316 \mathrm{pp}$.

17. Wardlaw, C. W., 1972. Banana diseases including plantains and abaca. 2nd ed. Longmans, London. 878 pp. 